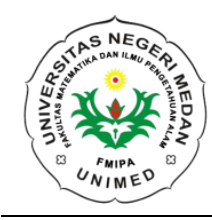

\author{
JURNAL EINSTEIN \\ Jurnal Hasil Penelitian Bindang Fisika \\ Available online http://jurnal.unimed.ac.id/2012/index.php/einsten \\ e-issn: $2407-747 x$, p-issn $2338-1981$
}

\title{
ANALISIS RESISTIVITAS BAWAH PERMUKAAN MENGGUNAKAN METODE GEOLISTRIK KONFIGURASI WENNER_SCHLUMBERGER DAN DIPOLE-DIPOLE DI DAERAH GEOTHERMAL GUNUNG SIBAYAK KABUPATEN KARO PROVINSI SUMATERA UTARA
}

\author{
Arie Sapta Octavani dan Muhammad Kadri \\ Jurusan Fisika, Fakultas Matematika dan Ilmu Pengetahuan Alam, Universitas Negeri Medan, \\ Indonesia \\ arhyie_7@yahoo.com \\ Diterima April 2018; Disetujui Mei 2018; Dipublikasikan Juni 2018
}

\begin{abstract}
ABSTRAK
Penelitian ini bertujuan untuk menentukan penyebaran batuan dan fluida yang terdapat di bawah permukaan daerah potensi panas bumi Gunung Sibayak Kabupaten Karo Provinsi Sumatera Utara. Berdasarkan analisa nilai resistivitasnya dengan menggunakan metode geolistrik konfigurasi Wenner-Schlumberger dan Dipole-Dipole. Penelitian dilakukan dengan menggunakan metode geolistrik konfigurasi Wenner-Schlumberger dan Dipole-Dipole yang didasari dengan hukum Ohm untuk mengetahui resistivitas jenis perlapisan batuan pada tiap lapisan permukaan bumi. Dengan menginjeksikan arus melalui dua elektroda arus maka beda potensial yang muncul dapat terukur dari elektroda potensial. Variasi harga tahanan jenis akan didapatkan jika jarak masing-masing elektroda diubah, sesuai dengan konfigurasi WennerSchlumberger dan Dipole-Dipole. Nilai tahanan jenis yang terukur bukan merupakan harga sebenarnya akan tetapi merupakan nilai tahanan jenis semu (Apparent Resisitivity). Kemudian data yang diperoleh ditampilkan dengan menggambarkan kontur 2D menggunakan software Res2dinv. Hasil penelitian menunjukkan bahwa adanya potensi geothermal di daerah penelitian dengan indikasi nilai hambatan yaitu $209 \Omega \mathrm{m}$ sampai dengan $442 \Omega \mathrm{m}$ pada lintasan pertama dengan konfigurasi Dipole-Dipole, $32.9 \Omega \mathrm{m}$ sampai dengan $79.0 \Omega \mathrm{m}$ pada lintasan kedua dengan konfigurasi Wenner-Schlumberger, $4.56 \Omega \mathrm{m}$ sampai dengan $18.7 \Omega \mathrm{m}$ pada lintasan kedua dengan konfigurasi Dipole-Dipole. Hasil penelitian juga menunjukkan bahwa nilai resistivitas lintasan kedua antara konfigurasi Wenner-Schlumberger dengan Dipole-Dipole mempunyai nilai resistivitas yang sedikit berbeda yang disebabkan oleh kedalaman yang berbeda dan nilai ketidakpastian alat yang berbeda.
\end{abstract}

Kata Kunci : Geolistrik, Konfigurasi Wenner-Schlumberger, Konfigurasi Dipole-dipole, Geothermal

\section{PENDAHULUAN}

Energi panas bumi adalah energi sumber daya alam berupa air panas atau uap yang terbentuk dalam reservoir di dalam bumi melalui pemanasan air bawah permukaan oleh batuan beku panas. Air permukaan yang berasal dari sungai, hujan, danau, laut dan lain-lain meresap menjadi air tanah, mengalir dan bersentuhan dengan tubuh magma atau batuan beku panas tersebut, mendidih serta kemudian membentuk 
Arie Sapta Octavani dan Muhammad Kadri, Analisis Resistivitas Bawah Permukaan Menggunakan Metode Geolistrik Konfigurasi Wenner-Schlumberger Dan Dipole-Dipole Di Daerah Geothermal Gunung Sibayak Kabupaten Karo Provinsi Sumatera Utara

air dan uap panas (Hidrothermal). Karena berat jenis, temperatur dan tekanannya, uap dan air panas ini mengalir kembali ke permukaan melalui bidang-bidang rekahan di lapisan kulit bumi (Tim Pertamina, 2007).

Panas bumi adalah sumber daya panas alami yang terdapat di dalam bumi, yang disebabkan oleh hasil interaksi antara panas yang dipancarkan batuan panas (magma) dan air tanah yang berada disekitarnya, dimana cairan yang terpanasi terperangkap di dalam batuan yang terletak di dekat permukaan (Setyaningsih, W. 2011).

Potensi panas bumi di Indonesia yaitu sekitar 28170 MW atau 30-40\% potensi sumber daya panas bumi di dunia. Setelah dilakukan beberapa survei terkait potensi panas bumi di Indonesia, terdapat 265 area prospek panas bumi. Persebaran potensi panas bumi yaitu 84 prospek di Pulau Sumatera, 76 prospek di Pulau Jawa, 51 prospek di Pulau Sulawesi, 21 prospek di Nusa Tenggara, 3 prospek di Irian Jaya, 15 prospek di Maluku dan 5 prospek di Kalimantan. Berdasarkan penelitian yang dilakukan Pertamina (1995) Indonesia mempunyai potensi sumber panas bumi entalpi tinggi sebesar 19.700 MW yang berasal dari berbagai pulau seperti : Sumatera (9550 MW), Jawa-Bali (5700 MW), Sulawesi (1600 MW), pulau lainnya (2850 MW) dan baru $\pm 4 \%$ dari keseluruhan potensi panas bumi yang sudah dimanfaatkan.

Salah satu daerah di Indonesia yang menyimpan potensi sumber energi panas bumi yang tinggi adalah Provinsi Sumatera Utara, dikarenakan Kepulauan Sumatera terletak pada pertemuan lempeng utama dunia yaitu lempeng Eurasia dan lempeng Australia. Salah satu daerah yang memiliki indikasi adanya sumber energi panas bumi di Sumatera Utara adalah di gunung sibayak Kabupaten Karo.

Untuk menggali potensi panas bumi di daerah gunung Sibayak Kabupaten Karo, cara yang dapat dilakukan untuk mengeksploitasi energi panas bumi adalah dengan memanfaatkan ilmu Geofisika. Dalam penelitian ini, peneliti menggunakan metode geolistrik (Resistivity), dimana metode geolistrik ialah salah satu metode geofisika yang cukup banyak digunakan dalam dunia eksplorasi khususnya eksplorasi air tanah karena resistivitas dari batuan sangat sensitif terhadap kandungan airnya.

Penelitian ini menggunakan metode geolistrik dengan mengkombinasikan dua konfigurasi yaitu konfigurasi WennerSchlumberger dan Dipole-Dipole. Dengan kombinasi konfigurasi Wenner-Schlumberger dan Dipole-Dipole dapat dilihat perbandingan nilai resistivitas batuan dan fluida pada obyek yang diteliti. Pada metode geolistrik resistivitas konfigurasi Wenner-Schlumberger jarak antara elektroda arus dan elektroda potensial adalah $\mathrm{n}$ kali jarak kedua elektroda potensial. Metode geolistrik resistivitas konfigurasi Dipole-Dipole adalah metode yang digunakan untuk mengidentifikasi jenis batuan bawah permukaan berdasarkan nilai resistivitas batuan yang memusat pada obyek yang diteliti.

Untuk penelitian penentuan harga resistivitas terhadap penyebaran fluida geothermal sebelumnya sudah dilakukan, hanya saja lokasi penelitian dilakukan di daerah sumber panas bumi gunung Sibual-bual Sipirok Tapanuli Selatan dan peneliti tersebut hanya menggunakan metode geolistrik schlumberger (Haerudin, 2008). Di daerah Tambu Kabupaten Donggala Provinsi Sulawesi Tengah dengan tahanan jenis 70 - $150 \Omega \mathrm{m}$, lapisan ini berada pada kedalaman $>600$ meter, diikuti oleh lapisan batolit granit yang mendominasi lapisan batuan di daerah ini dengan tahanan jenis $800-900 \Omega \mathrm{m}$, di daerah Rianiate Kecamatan Pangururan berkisar antara 23,6 - 84,7 $\Omega \mathrm{m}$ pada kedalaman dari 6,36 - 9,26 meter. Aplikasi dari metode geolistrik resistivitas konfigurasi Dipole-Dipole pernah dilakukan di daerah Takaoi Kabupaten Kahayan Hulu, Kalimantan Tengah yang menunjukkan dengan jelas adanya tiga lapisan tanah penutup dengan ketebalan rata-rata 3 meter, lapisan aluvium dengan ketebalan ratarata 7 sampai 10 meter, dan batuan dasar pada kedalaman antara 10 sampai 15 meter (Priatna, 2000).

\section{Alat Penelitian}

Dalam melakukan pengukuran resistivitas bawah permukaan, perlengkapan yang digunakan adalah GPS (Global Position System), 
Geolistrik ARES-D4.v47, SN: 06091345, Palu, Baterai /Aki 60 A, HT, Laptop.

\section{Teknik Pengolahan Data}

Dari beberapa konfigurasi geolistrik metode tahanan jenis yang ada, akan digunakan konfigurasi Wenner-Schlumberger dan DipoleDipole. Setelah data diperoleh maka dilakukan perhitungan $\rho$ semu atau tahanan jenis semu dengan rumus :

$$
\rho=\frac{\Delta V}{I} K
$$

Wenner-Schlumberger

$$
\rho_{\alpha}=\frac{\Delta V}{I} \pi n(n+1) \alpha
$$

Dipole-Dipole

$$
\rho_{\alpha}=\frac{\Delta V}{I} \operatorname{\pi an}(n+1)(n+2)
$$

Nilai $\rho$ semu ini akan digunakan dalam pembuatan peta tahanan jenis semu yang dikorelasikan dengan data tahanan jenis 1D Sounding. Setelah melakukan perhitungan $\rho$ (resistivity) berdasarkan data tahanan jenis 1D Sounding, dibuat kurva resistivitas. Input data 1D Sounding dimasukkan dalam software Res2Dinv sehingga menghasilkan kurva resistivitas antara kedalaman dengan harga resistivitas lainnya. Dari hasil perhitungan $\rho$ semu yang telah dilakukan maka data diolah dengan pemodelan 1D dari titik ukur data resistivitas dan kedalaman di Res2Dinv.

\section{Analisis Data}

1. Melakukan pengolahan awal dari data yang diperoleh berdasarkan pengukuran untuk menghitung nilai resistivitas semu $\left(\rho_{a}\right)$ tiap datum point

2. Kemudian data jarak datum (a), $\mathrm{n}$ dan nilai resistivitas semu $\left(\rho_{a}\right)$ tersebut dimasukkan ke program notepad dan disimpan dengan nama file tertentu yang nantinya akan dipanggil pada program Res2DinV (sesuai aturan software Res2DinV).

3. Dari pemodelan 2D dengan Res2DinV diperlihatkan nilai resistivitas dan kedalaman untuk setiap lapisannya.

4. Nilai resistivitas material pada model yang diperoleh berdasarkan hasil pengukuran dicocokkan dengan nilai resistivitas material berdasarkan referensi untuk mengetahui ada tidaknya kesesuaian.

\section{Rumusan Pengukuran}

Besaran $\mathrm{V}$ pada rumusan potensial secara pengukuran dapat dinyatakan sebagai beda potensial $\delta \mathrm{V}$ antara potensial pada kondisi tanpa arus (V0) dan pada kondisi dengan arus (V1), yaitu dengan pengukuran potensial diantara elektroda P1 dan P2 (elektroda potensial), selanjutnya mengukur kuat arus yang mengalir diantara elektroda C1 dan C2 (elektroda arus). Konfigurasi yang digunakan dalam penelitian ini adalah Wenner-Schlumberger dan Dipole-Dipole. Resistivitas semu ( $\rho$ a) dititik pengukuran dapat diperkirakan melalui rumusan :

Wenner-Schlumberger

$$
\rho_{\alpha}=\frac{\Delta V}{I} \pi n(n+1) a
$$

Dipole-Dipole

$$
\rho_{\alpha}=\frac{\Delta V}{I}=\operatorname{\pi an}(n+1)(n+2)
$$

Dimana;

$\mathrm{K}=\pi n(n+1) a$ adalah faktor geometri untuk konfigurasi Wenner Schlumberger

$\mathrm{K}=\operatorname{\pi an}(n+1)(n+2)$

$\mathrm{a}=$ jarak antara elektroda $\mathrm{P}_{2}$ dan $\mathrm{P}_{2}$

$\mathrm{a}=\left(\mathrm{P}_{1}-\mathrm{P}_{2}\right)^{*}$ jarak spasi terkecil elektroda

$\mathrm{n}=$ bilangan bulat bulat $(\mathrm{n}=1,2,3, \ldots .$.

$\mathrm{n}=(\mathrm{C} 1-\mathrm{P} 1) /(\mathrm{C} 2-\mathrm{P} 2)$

\section{HASIL DAN PEMBAHASAN}

\section{Hasil Penelitian}

Setelah dilakukan pengambilan data dengan menggunakan alat geolistrik (Resistivity meter) ARES-G4 v4.7 SN: 0609135 (Automatic Resistivity System), dan GPS (Global Position System), di kedua lintasan yang telah ditentukan diperoleh data sebagai berikut:

Tabel 1. Hasil Pengukuran di Lapangan

\begin{tabular}{|c|c|l|c|l|}
\hline $\begin{array}{c}\text { Lintasa } \\
\mathrm{n}\end{array}$ & $\begin{array}{c}\text { Elektrod } \\
\mathrm{a}\end{array}$ & $\begin{array}{c}\text { Posis } \\
\mathrm{i}\end{array}$ & $\begin{array}{c}\text { AL } \\
\mathrm{T} \\
(\mathrm{m})\end{array}$ & Waktu \\
\hline $\mathrm{I}$ & $1(x)$ & $\mathrm{N}$ & 195 & 14.55 .3 \\
& & $03^{0}$ & 6 & 5 \\
& & 14 & & \\
& & $214^{\prime}$ & & \\
& & & & \\
& & $098^{0}$ & & \\
\hline
\end{tabular}


Arie Sapta Octavani dan Muhammad Kadri, Analisis Resistivitas Bawah Permukaan Menggunakan Metode Geolistrik Konfigurasi Wenner-Schlumberger Dan Dipole-Dipole Di Daerah Geothermal Gunung Sibayak Kabupaten Karo Provinsi Sumatera Utara

\begin{tabular}{|c|c|c|c|c|}
\hline & & $\begin{array}{l}30^{\prime} \\
112^{\prime \prime}\end{array}$ & & \\
\hline & $16(y)$ & $\begin{array}{l}\mathrm{N} \\
03^{0} \\
14^{\prime} \\
246^{\prime \prime} \\
\mathrm{E} \\
098^{0} \\
30^{\prime} \\
130^{\prime \prime}\end{array}$ & $\begin{array}{c}193 \\
7\end{array}$ & $\begin{array}{l}13.58 .0 \\
9\end{array}$ \\
\hline & $32(z)$ & $\begin{array}{l}\mathrm{N} \\
03^{0} \\
14^{\prime} \\
279^{\prime} \\
\mathrm{E} \\
098^{0} \\
30^{\prime} \\
152^{\prime}\end{array}$ & $\begin{array}{c}195 \\
6\end{array}$ & $\begin{array}{l}15.12 .0 \\
9\end{array}$ \\
\hline \multirow[t]{3}{*}{ II } & $1(x)$ & $\begin{array}{l}\mathrm{N} \\
03^{0} \\
14^{\prime} \\
138^{\prime \prime} \\
\mathrm{E} \\
098^{0} \\
29^{\prime} \\
841^{\prime \prime}\end{array}$ & $\begin{array}{c}180 \\
8\end{array}$ & $\begin{array}{c}18.44 .1 \\
3\end{array}$ \\
\hline & $16(y)$ & $\begin{array}{l}\mathrm{N} \\
03^{0} \\
14^{\prime} \\
168^{\prime \prime} \\
\mathrm{E} \\
098^{0} \\
29^{\prime} \\
816^{\prime \prime}\end{array}$ & $\begin{array}{c}180 \\
9\end{array}$ & $\begin{array}{l}18.58 .2 \\
9\end{array}$ \\
\hline & $32(z)$ & $\begin{array}{l}\mathrm{N} \\
03^{0} \\
14 \\
169^{\prime} \\
\mathrm{E} \\
098^{0} \\
29^{\prime} \\
774^{\prime \prime}\end{array}$ & $\begin{array}{c}180 \\
7\end{array}$ & $\begin{array}{l}18.54 .1 \\
5\end{array}$ \\
\hline
\end{tabular}

\section{Pengolahan Data}

Setelah dilakukan pengambilan data di lapangan dengan menggunakan alat geolistrik maka didapatkan hasil data nilai resistivitas dari tiap-tiap titik, kemudian data tersebut dikalikan dengan faktor tersebut dikalikan dengan faktor geometri (konfigurasi Wenner-Schumberger dan
Dipole-Dipole) untuk mendapatkan harga resistivitas semua ( $\rho s$

Setelah dilakukan pengambilan data dengan menggunakan alat geolistrik (Resistivity Meter), ARES-G4 v4,7 SN: 0609135 (Autematic Resistivity System), GPS (Global Position System), di kedua lintasan yang telah ditentukan kemudian dilakukan pengunduhan data maka didapatkan hasil data tentang resistivitas dari tiap-tiap titik, kemudian data tersebut dikalikan dengan faktor geometri (konfigurasi Schumberger) umtuk mendapatkan nilai resistivitas semua ( $\rho$ ) yang akan digunakan dalam membuat kontur dengan menghubungkan tiap-tiap nilai resistivitas semu ( $\rho$ ) tersebut.

Dalam tahap pengolahan data ini dilakukan menggunakan komputer dengan software Res2Dinv, software ini mengolah data yang diperoleh dari lapangan. Pemodelan 2-D dilakukan dengan menggunakan program inverse yang mana program inversi ini menggambarkan 2-D. Program inversi ini juga menentukan harga resistivitas semu terukur dan terhitung. Metode inversi yang digunakan dalam penelitian ini adalah metode kuadrat terkecil (least square).

Dari data pengukuran dan perhitungan di lapangan kemudian diinterpretasikan menggunakan software Res2Dinv untuk memperlihatkan profil bawah permukaan area yang diukur. Software Res2Dinv (2D) digunakan untuk menampilkan profil 2 dimensi sehingga data pengukuran di lapangan menggunakan konfigurasi Mapping.

\section{Hasil Analisis dan Interpretasi Data}

Tampilan 2-D hasil dari pengolahan data dengan menggunakan software Res2Dinv tersebut terdiri dari tiga kontur resistivitas pada penampang kedalaman semu (pseudodepth section). Penampang yang pertama menunjukkan kontur resistivitas semu pengukuran (measured apparent resistivity pseudosection), yaitu data resistivitas semu yang diperoleh dari pengukuran di lapangan. Penampang yang kedua menunjukkan kontur resistivitas dari hasi perhitungan (calculated apparent resistivity pseudosection), dan penampang yang ketiga adalah kontur resistivitas yang sebenarnya yang diperoleh setelah melalui 
proses pemodelan inversi (inverse model resistivity section).

Data resistivitas 2-D yang telah diolah menggunakan program Res2Dinv, kemudian diperoleh gambaran 2-D bawah permukaan sepanjang lintasan dimana nilai tahanan jenis yang dibedakan dengan warna untuk melihat kontras resistivitas pada setiap lapisan dan memberikan informasi tahanan jenis sebenarnya secara lateral (mengikuti rekahan ke permukaan bumi) dan vertikal. Analisis data ini dilakukan untuk setiap lintasan ggeolistrik 2-D, sehingga dapat diperkirakan keadaan bawah permukaan yang lebih rinci.

\section{- Lintasan Pertama}

\section{- Metode Konfigurasi Dipole-dipole}

Data yang diperoleh dengan menggunakan alat geolistrik (Resistivity meter), ARES-G4 v4.7 SN: 0609135 (Automatic Resistivity System). Adalah nilai rsistivitas semu bervariasi karena struktur bawah tanah sangat bervariasi, nilainya 2,32 $\Omega \mathrm{m}$ sampai dengan $442 \Omega \mathrm{m}$. Panjang lintasan pertama adalah 160 meter, jarak antara elektroda 5 meter. Setelah diinversikan dengan software Res2Dinv diperoleh gambar penampang seperti gambar di bawah ini:

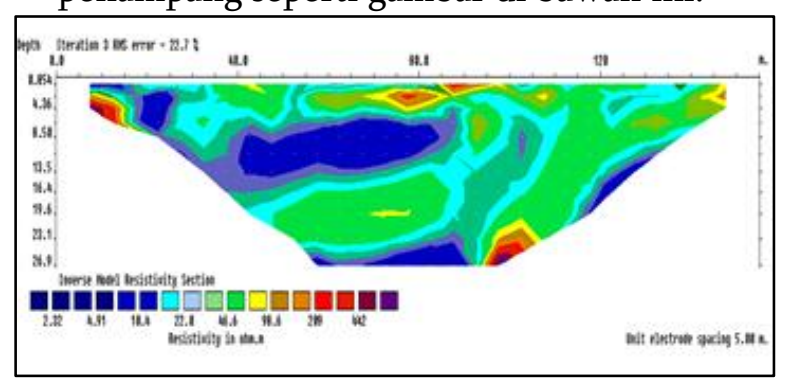

Gambar 1. Penampang Kontur Resistivitas Pada Lintasan Pertama

\section{Konfigurasi Dipole-Dipole}

Berdasarkan penampang kontur resistivitas semu pada lintasan pertama konfigurasi Dipole-Dipole, dapat diketahui harga resistivitas masing-masing pada tiap lapisan beda.

Tabel 2. Interpretasi Lintasan I

\begin{tabular}{|c|c|c|c|}
\hline No & $\begin{array}{c}\text { Resistivitas } \\
(\Omega \mathrm{m})\end{array}$ & $\begin{array}{c}\text { Kedalaman } \\
(\mathrm{m})\end{array}$ & Interpretasi \\
\hline 1. & $2,32-22,0$ & $4,36-16,4$ & tanah lanau \\
\hline 2. & $46,6-98,6$ & $1,5-23,1$ & $\begin{array}{c}\text { lempung dan } \\
\text { pasiran }\end{array}$ \\
\hline
\end{tabular}

\begin{tabular}{|c|c|c|c|}
\hline 3 & $209-442$ & $10,5-24,5$ & $\begin{array}{c}\text { lapisan tanah } \\
\text { lanau dan pasiran }\end{array}$ \\
\hline
\end{tabular}

Berdasarkan gambar 1 dapat dianalisis bahwa pada setiap lapisan memiliki nilai resistivitas yang berbeda-beda yang berkisar antara $2,32 \Omega \mathrm{m}$ hingga $442 \Omega \mathrm{m}$. Dari gambar terdapat beberapa titik air panas yang ditunjukkan dengan warna merah dan ungu pada jarak 7,5 sampai 12,5 meter yang memiliki nilai resistivitas paling tinggi berkisar $209-442 \Omega \mathrm{m}$. Sedangkan untuk warna biru muda merupakan aliran fluida dengan nilai resistivitas $22,0 \Omega \mathrm{m}$, sedangkan warna biru tua merupakan air yang terpanaskan dengan nilai resistivitas 2,32 - 10,4 $\Omega \mathrm{m}$. Serta gambar yang menunjukkan warna hijau muda hingga kuning kecoklatan dengan nilai resistivitas 46,6-98,6 $\Omega$ m merupakan tanah lanau dan pasiran.

- Lintasan Kedua

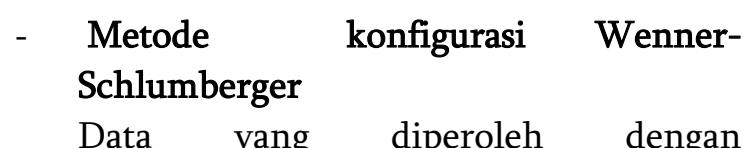
menggunakan alat geolistrik (Resistivity meter), ARES-G4 v4.7 SN: 0609135 (Automatic Resistivity System). Nilai resistivitas semu bervariasi karena struktur bawah tanah sangat bervariasi, nilainya $13,7 \Omega \mathrm{m}$ sampai dengan 294 $\Omega \mathrm{m}$. Panjang lintasan pertama adalah 160 meter, jarak antara elektroda 5 meter. Setelah diinversikan dengan software Res2Dinv diperoleh gambar penampang seperti gambar di bawah ini:

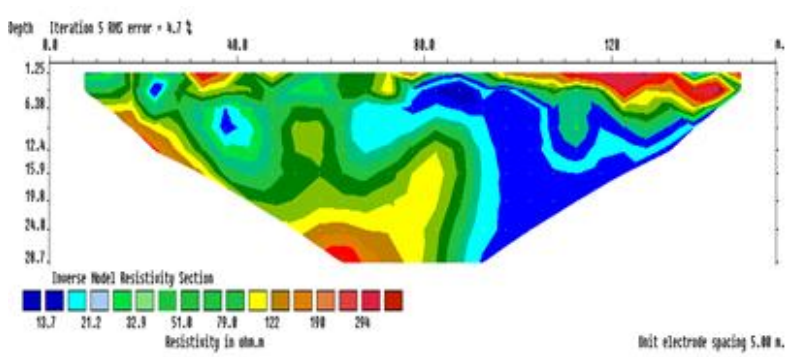

\section{Gambar 2. Penampang Kontur Resistivitas Pada Lintasan Kedua Konfigurasi Wenner-Schlumberger}

Berdasarkan penampang kontur resistivitas semu pada lintasan kedua konfigurasi Wenner-Schlumberger, dapat diketahui harga resistivitas masing-masing pada tiap lapisan beda.

Tabel 3. Interpretasi Lintasan II Konfigurasi Wenner-Schlumberger 
Arie Sapta Octavani dan Muhammad Kadri, Analisis Resistivitas Bawah Permukaan Menggunakan Metode Geolistrik Konfigurasi Wenner-Schlumberger Dan Dipole-Dipole Di Daerah Geothermal Gunung Sibayak Kabupaten Karo Provinsi Sumatera Utara

\begin{tabular}{|c|c|c|c|}
\hline No & $\begin{array}{c}\text { Resistivitas } \\
(\Omega \mathrm{m})\end{array}$ & $\begin{array}{c}\text { Kedalaman } \\
(\mathrm{m})\end{array}$ & Interpretasi \\
\hline 1. & $13,7-21,2$ & $6,0-24,0$ & $\begin{array}{c}\text { lanau } \\
\text { lembek }\end{array}$ \\
\hline 2. & $32,9-79,0$ & $6,38-19,8$ & $\begin{array}{c}\text { tanah lanau } \\
\text { dan pasiran }\end{array}$ \\
\hline 3 & $122-294$ & $1,25-24,0$ & $\begin{array}{c}\text { lempung } \\
\text { dan pasiran }\end{array}$ \\
\hline
\end{tabular}

Berdasarkan gambar 2 dapat dianalisis bahwa pada setiap lapisan memiliki nilai resistivitas yang berbeda-beda yang berkisar antara $13,7 \Omega \mathrm{m}$ hingga $294 \Omega \mathrm{m}$. Dari gambar terdapat beberapa titik air panas yang ditunjukkan dengan warna cokelat dan merah pada jarak 52,5 sampai 75,0 meter yang memiliki nilai resistivitas paling tinggi berkisar $190-294$ $\Omega$. Sedangkan untuk warna biru dan biru muda merupakan aliran fluida dengan nilai resistivitas 13,7 - 21,2 $\Omega$, sedangkan warna hijau muda, hijau dan hijau tua merupakan air yang terpanaskan dengan nilai resistivitas $32,9-79,0 \Omega$. Serta gambar yang menunjukkan warna kuning dengan nilai resistivitas $122 \Omega$ merupakan lapisan tanah lanau.

\section{- Metode Konfigurasi Dipole-Dipole}

Data yang diperoleh dengan menggunakan alat geolistrik (Resistivity meter), ARES-G4 v4.7 SN: 0609135 (Automatic Resistivity System). Adalah nilai rsistivitas semu bervariasi karena struktur bawah tanah sangat bervariasi, nilainya $4,56 \Omega \mathrm{m}$ sampai dengan 640 $\Omega \mathrm{m}$. Panjang lintasan pertama adalah 160 meter, jarak antara elektroda 5 meter. Setelah diinversikan dengan software Res2Dinv diperoleh gambar penampang seperti gambar di bawah ini :

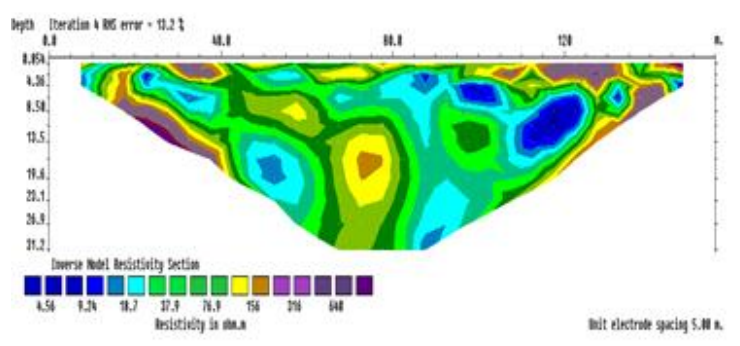

Gambar 3. Penampang Kontur Resistivitas Pada Lintasan Kedua

\section{Konfigurasi Dipole-Dipole}

Berdasarkan penampang kontur resistivitas semu pada lintasan kedua konfigurasi Dipole-Dipole, dapat diketahui harga resistivitas masing-masing pada tiap lapisan beda.

Tabel 4. Interpretasi Lintasan II Konfigurasi Dipole-Dipole

\begin{tabular}{|c|c|c|c|}
\hline No & $\begin{array}{c}\text { Resistivitas } \\
(\Omega \mathrm{m})\end{array}$ & $\begin{array}{c}\text { Kedalaman } \\
(\mathrm{m})\end{array}$ & Interpretasi \\
\hline 1. & $4,56-18,7$ & $6,30-30,5$ & Tanah lanau \\
\hline 2. & $37,9-156$ & $37,9-23,1$ & $\begin{array}{c}\text { tanah lanau } \\
\text { dan pasiran }\end{array}$ \\
\hline 3 & $316-640$ & $\begin{array}{c}0,854- \\
8,50\end{array}$ & $\begin{array}{c}\text { Tanah basah } \\
\text { lembek }\end{array}$ \\
\hline
\end{tabular}

Berdasarkan gambar 3. dapat dianalisis bahwa pada setiap lapisan memiliki nilai resistivitas yang berbeda-beda yang berkisar antara $4,56 \Omega \mathrm{m}$ hingga $640 \Omega \mathrm{m}$. Dari gambar terdapat beberapa titik air panas yang ditunjukkan dengan warna ungu muda dan ungu tua pada jarak 17,5 sampai 40,0 meter yang memiliki nilai resistivitas paling tinggi berkisar 316 - $640 \Omega$. Sedangkan untuk

hijau merupakan aliran fluida dengan nilai resistivitas 37,9 - 76,9 $\Omega$, sedangkan warna biru tua dan biru merupakan air yang terpanaskan dengan nilai resistivitas 4,56-18,7 $\Omega$. Serta gambar yang menunjukkan warna kuning dan cokelat dengan nilai resistivitas $156 \Omega$ merupakan lapisan tanah lanau, tanah lanau lembek dan pasiran.

Pengambilan data oleh alat geolistrik pada tiap lintasan membutuhkan waktu yang berbeda-beda. Kondisi tanah yang lembab sangat baik untuk melakukan penelitian ini, karena elektroda yang dipakai sangat bergantung pada air untuk dapat mengukur nilai resistivitas lapisannya yang akan dibaca oleh alat saat pengukuran.

Dari hasil analisa pada ke dua lintasan, lapisan batuan di daerah penelitian adalah lapisan tanah lanau pasiran,tanah lanau lembek, tanah lempung lanau basah, batuan dasar terisi tanah kering, lapisan batuan dasar berkekar terisi tanah lembek dan pasir kerikil terdapat lapisan lanau.

\section{KESIMPULAN DAN SARAN}


Dari hasil pengolahan, analisis dan interpretasi data pada penelitian dapat diambil kesimpulan sebagai berikut :

1. Pola penyebaran fluida geothermal pada daerah penelitian tersebar secara lateral, dimana lapisan pasiran sebagai zona konduktif dan lapisan tanah lanau sebagai lapisan penutupnya.

2. Hasil penelitian menunjukkan bahwa adanya potensi geothermal di daerah penelitian dengan indikasi nilai hambatan yaitu $209 \Omega \mathrm{m}$ sampai dengan $442 \Omega \mathrm{m}$ pada lintasan pertama dengan konfigurasi Dipole-Dipole, $32.9 \Omega \mathrm{m}$ sampai dengan $79.0 \Omega \mathrm{m}$ pada lintasan kedua dengan konfigurasi WennerSchlumberger, $4.56 \Omega \mathrm{m}$ sampai dengan $18.7 \Omega \mathrm{m}$ pada lintasan kedua dengan konfigurasi Dipole-Dipole.

3. Hasil penelitian menunjukkan bahwa nilai resistivitas lintasan kedua antara konfigurasi Wenner-Schlumberger dengan Dipole-Dipole mempunyai nilai resistivitas yang sedikit berbeda yang disebabkan oleh kedalaman yang berbeda.

4. (lintasan I dan II) memiliki penyusun yang sama, tetapi hanya nilai resistivitas dan kedalamannya saja yang berbeda. Dari kedalaman 0,854-31,2 meter jenis tanah/batuannya adalah tanah lanauan, tanah lanau lembek dan pasiran.

\section{SARAN}

Dilihat dari pola penyebaran fluida geothermal, maka perlu dilakukan penelitian lebih lanjut dengan memperluas daerah pengambilan data dan mengubah tata cara peletakan rentangan kabel elektroda-elektroda yang akan digunakan, sehingga potensinya akan lebih terlihat. Perlu diadakan penelitian lebih lanjut pada tempat penelitian dengan menggunakan metode termometer empiris dan metode magnetik untuk mendapatkan data yang lebih maksimal sebagai referensi pemanfaatan panas bumi.

\section{DAFTAR PUSTAKA}

Haerudin, N., dan Rasimen, E., (2008), Metode Geolistrik Untuk Menentukan Pola
Penyebaran Fluida Geothermal Di Daerah Potensi Panasbumi Gunung Rajabasa Kalianda Lampung Selatan, Prosiding Seminar Nasional SATEKS II Universitas Lampung. Bandar lampung.

Kurniawan, A., (2009), Eksplorasi Energi Panas

Bumi Dengan Metode Geofisika Dan Geokimia Pada Daerah RiaRia Sipoholon, Kabupaten Tapanuli Utara, Sumatra Utara, Skripsi, Teknik Geologi, ITB, Bandung.

Minarto, E., (2007), Pemodelan Inversi Data Geolistrik Untuk Menentukan Struktur Perlapisan Bawah Permukaan Daerah Panas bumi Mataloko, Jurnal geofisika, Surabaya.

Reynolds, J.M., (1997), An Introduction to Applied and Enviromental Geophysics. John Wiley \& Sons, New York.

Tim Pertamina, (2007), Peluang Pemanfaatan

Potensi Energi Geothermal Ulubelu Lampung. Makalah Workshop Geofisika Universitas Lampung, Bandar Lampung

Wardhana, W.A., Supriyono, A.Z., Kamal, Z., (1998), Prosfek Panas Bumi di Indonesia, http://www.bag.lapan.go.id. (accessed 27 Maret 2008). 